\title{
Physical-mechanical performance criteria of cement-soil mortars for earth building coating
}

\author{
Parâmetros de desempenho físico-mecânico das \\ argamassas de solo-cimento para revestimento de \\ construções com terra
}

\section{Ana Paula da Silva Milani \\ Flávia Gaspar Rangel Dias}

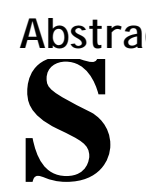

oil as a mortar aggregate may improve the physical-mechanical compatibility between the coating system and earth-wall substrate, as well as present greater durability when stabilised with cement. Based on these concepts, the physical-mechanical behaviour of mortars comprising soil, cement, lime and admixture was analysed to be used as coating for earth constructions. Cement-soil mortars using the ratio of sandy soil equal to or less than 1:6 in the cement:soil dosage shows a potential for an application as earth wall coating. However, to improve its workability in the fresh state, it is necessary to add hydrated lime or chemical admixture at a limited proportion so it does not damage the physical performance of the mortar. To qualify the cement-soil mortars for earth building coating, the minimum requirements for volumetric shrinkage, tensile bond strength and compressive strength must be met simultaneously and the following criteria are indicated: minimum compressive strength of $4 \mathrm{MPa}$; zero volumetric shrinkage index and minimum tensile bond strength of $0.20 \mathrm{MPa}$.

Keywords: Hydrated lime. Admixture. Bonding. Workability. Shrinkage.

\section{Resumo}

O solo como agregado na argamassa pode melhorar a compatibilidade físicomecânica entre o sistema de proteção e a parede de terra, bem como apresentar maior durabilidade a partir de sua estabilização com cimento. Nessas premissas, foram estudadas argamassas compostas de solo, cimento, cal e aditivo químico, e analisado o seu comportamento físico-mecânico quando utilizadas para o revestimento de construções com terra. As argamassas de solo-cimento que usam a proporção de solo arenoso igual ou menor que 1:6 no traço cimento:solo apresentam potencialidade de aplicação como revestimento de parede. No entanto, para melhorar sua trabalhabilidade

Ana Paula da Silva Milani Universidade Federal de Mato Grosso Campo Grande - MS - Brasil

Flávia Gaspar Rangel Dias Universidade Federal de Mato Grosso Campo Grande - MS - Brasil

Recebido em 20/03/17 Aceito em 14/12/17 no estado fresco devem ser utilizados a cal hidratada ou o incorporador de ar, ressaltando um limite de adição para não interferir negativamente no desempenho físico da argamassa. Para qualificar as argamassas de solocimento para revestimentos de construções com terra deve-se alcançar simultaneamente os requisitos mínimos de retração volumétrica por secagem e de resistências de aderência à tração e à compressão axial, sendo indicados os seguintes parâmetros de desempenho físico-mecânico: resistência a compressão axial mínima de $4 \mathrm{MPa}$; índice de retração volumétrica nulo e resistência de aderência à tração mínima de 0,20 MPa.

Palavras-chaves: Cal hidratada. Aditivo químico. Aderência à tração. Trabalhabilidade. Retração. 


\section{Introduction}

Searching for buildings that develop concepts of sustainability and energy efficiency, as well as cement-stabilised earth based construction has been highlighted (KARIYAWASAM; JAYASINGHE, 2016; CORREIA et al., 2016). Even though cement-soil use as a construction material has increased, there are few technical specifications and standards regarding its use, especially concerning its dimensions, compositions, dosage or for the different techniques of applications such as blocks, bricks or rammed earth walls, let alone for bonding, coating and the recovery of mortars. Focusing on wall coating, Kanan (2008) and Syrmakezis et al. (2013) studied the use of soil-lime mortars to protect and conserve earth buildings.

According to Arizzi and Cultrone (2013) and Carasek et al. (2014), one of the biggest problems using soil as an aggregate in cement mortar is the presence of silt and clay because when applied to the wall coating, they influence the workability of the mixture, cracking susceptibility and bonding. Reddy and Gupta (2006) observed that bond strength of cement-soil mortar decreases with the increase in clay content in the mortar.

Mateus, Veiga and Brito (2015) defined some important characteristics that mortars must have to rehabilitate constructions made of soil as it is common to use lime-soil-sand composites to protect rammed earth walls in Portugal. According to the authors, the better compressive strength of rehabilitating mortars in relation to the earth wall strength generates excessive tensions in the coating/wall interface, causing cracking, loss of adherence and laminar detachments of the coating surfaces. Furthermore, the small proportion of lime in the mortars might cause the presence of powdery materials, of different natures that have a clayey base, that justify the higher water absorption and lower durability of the earth wall.

To achieve a better physical-mechanical compatibility between the coating surface and the earth wall substrate, the soil as aggregate can be more appropriate for the performance of the earth walls against the strain because the coating and the wall composed of earth would have the tendency to obtain a similar elasticity modulus (REDDY; GUPTA, 2005, 2008).

Some studies, such as that of Romera et al. (2013), show quicklime mortars as a solution to coat and rehabilitate old buildings. However, they cannot be used in a permanently moist environment and places with limited access to carbon dioxide. It also needs specialised personnel for its application.
It is necessary to study mortars composed of hydraulic binders and soil to establish adequate proportions of their components, their mechanical strength and durability.

Conventional mortars have a clear performance and classification criteria based on guidelines and standards, such as CSTB (CENTRE..., 1982), NBR 13281 (ABNT, 2005a) and ASTM C780 (AMERICAN..., 2006), however these requirements are not compatible with cement-soil mortars and their physical-mechanic characteristics should be studied to serve as a guideline for them to be efficiently used as coating for earth walls.

\section{Materials and methods}

Considering the recommendations of Burroughs (2008) concerning the best type of soil to stabilise with Portland cement, a soil from MS/Brazil was used, classified as A2-4 by the AASHTO criteria, composed of $66 \%$ sand and $34 \%$ fines (clay and silt), plasticity index non-plastic (NP), and a specific mass of $2.14 \mathrm{~g} / \mathrm{cm}^{3}$. In this research, this soil was called sandy-clay soil.

In order to verify the behaviour of different types of sandy-soils, $30 \%$ of soil was substituted with natural sand, classified as a fine sand. This composition is $82 \%$ sand (soil and natural sand) and $18 \%$ fines (clay and silt) and is non-plastic (NP). In this research, it was called sandy soil.

Cement-soil mortars were made using Portland Cement (CP $\mathrm{Z}$ - adding pozzolanic) and, to improve workability, hydrated lime was added (CH III - calcium and magnesium hydroxide) and chemical admixture (air entraining agent composed of vegetal resin and sodium hydroxide). The soil+cement+water mixtures with an addition of hydrated lime were homogenised and this mixture rested for 1 hour before running tests.

The cement-soil mortar dosage studies are shown in Figure 1. The water was added until the flow table of the mixture was $260 \pm 10 \mathrm{~mm}$. Still in the fresh state, the mortars underwent a water retention test. In the hardened state, the compression strength was tested at the ages of 7 and 28 days.

At the same time, tests to obtain the tensile bond strength between the cement-soil coating and soilcement block masonry wall were run. To this end, a soil-cement block wall was built using a cementlime-soil laying mortar at a ratio of 1:0.35:6.5; according to recommendations by Reddy and Gupta (2006), Ferreira and Moreno Junior (2011). Then, they were exposed to controlled conditions, relative humidity of $58 \pm 10 \%$ and a temperature 
of $22 \pm 1^{\circ} \mathrm{C}$ (Figure 2a). Cement-soil mortars were mixed and applied on the wall, forming panels with $40 \times 50 \mathrm{~cm}$ and a thickness of $1.5 \mathrm{~cm}$ for each dosage of cement-soil mortar (Figure 2b). The tensile bond strength test was carried out based on NBR 13528 (ABNT, 2005b) except for the attachment of only 6 metal cylinders in each mortar panel, glued for 48 hours with a low viscosity glue.

After statistical analyses of variance and completely randomised experimental coating in a factorial scheme and using the Tukey test ( $p$ $<0.05 \%$ ) to evaluate the mortars' physicalmechanic behaviour, the cement-soil mortars with compressive strength values between 4-12 $\mathrm{MPa}$ and tensile bond strength greater than or equal to $0.20 \mathrm{MPa}$ were selected.

The compressive strength criteria considered that in order to achieve compatibility between the protection system and the earth support, the mortar has to follow the physical-mechanical behaviour earth wall characteristics described by Reddy and Kumar (2011), in which the soil stabilised with cement presents a density around $1800 \mathrm{~kg} / \mathrm{m}^{3}$, compressive strength in the range of 3 to $5 \mathrm{MPa}$ and tangent modulus values up to $6400 \mathrm{MPa}$ for the mechanical strength of $12 \mathrm{MPa}$. For the tensile bond strength criteria, the NBR 13749 (ABNT, 1996) limits for single layer coatings of internal walls with a slim finish were used.

The choice of mortars was influenced by the recommendations of Oliveira et al. (2015) and Gattesco, Boem and Dudine (2015), by the minimal cement consumption per $\mathrm{m}^{3}$, lower admixture consumption, avoiding the increase of powdery material and the decrease of adherence; and water retention capacity greater than $75 \%$ to interfere minimally in plastic shrinkage, mechanical strength and the final finishing.

Polypropylene microfibres, $12 \mathrm{~mm}$ long, 12 $\mu \mathrm{m}$ diameter and $0.91 \mathrm{~g} / \mathrm{cm}^{3}$ of specific mass were used to improve the cement-soil mortars' behaviour in shrinkage and cracking. The fibres were added at a ratio of $0.3 \%$ (by weight of cement), according to recommendations by Toledo et al. (2005) and Ma et al. (2004).

Figure 1 - Mortar dosage

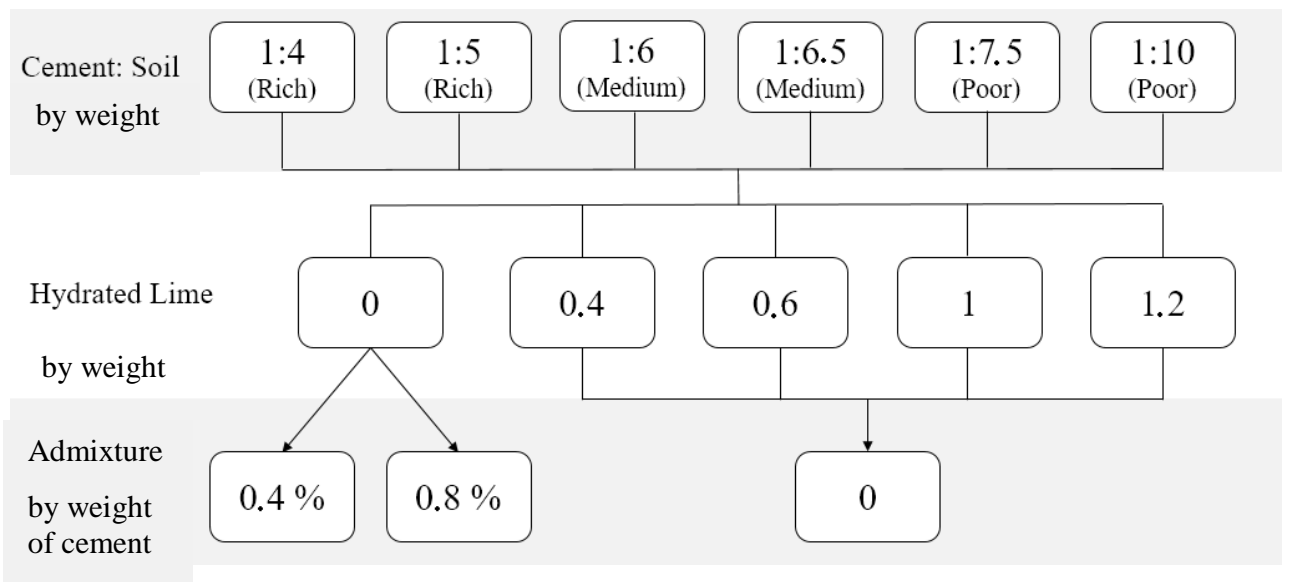

Figure 2 - (a) Soil-cement block wall and (b) Cement-soil mortar panel

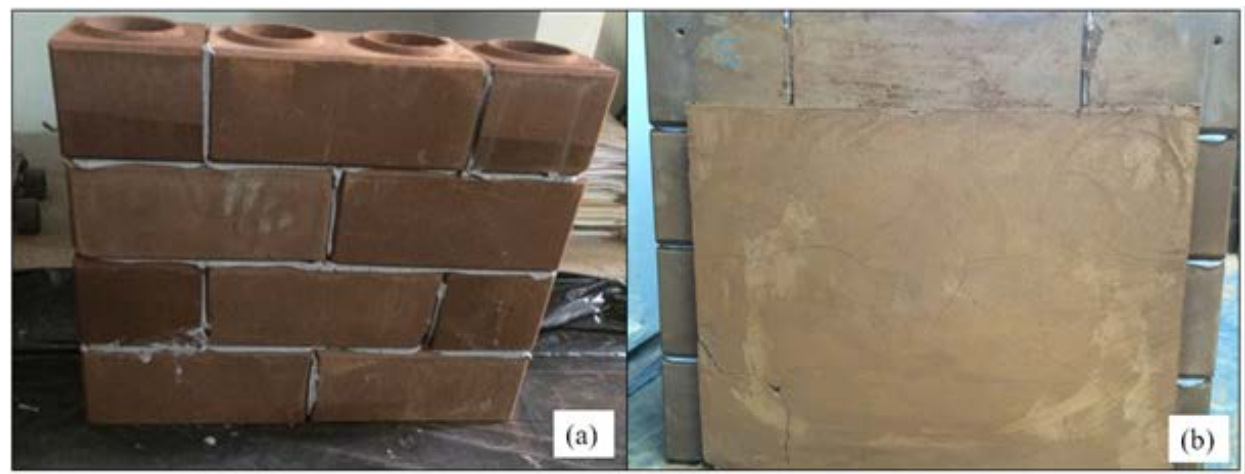


The physical behaviour of the mortars was verified by the shrinkage and cracking susceptibility during drying. The cracks were mapped according to recommendations by Veraldo, Yuba and Milani (2015) and Mauroux et al. (2012). The volumetric shrinkage test was adapted from ASTM C1579 (AMERICAN..., 2006) and Ceped (CENTRO..., 1984) and analysed by a correlation study between the shrinkage, tensile bond and compressive strength.

The cracks were analysed after using the mortars on the soil-cement block masonry walls that were constructed and cured in a temperature and moisture controlled condition (Figure 2b). In the first 24 hours, the time of the cracking formations were analysed, and after 28 days, its orientation, width and length were measured, using pictures and AutoCad. The relation between the sum of the cracks' lengths $(\Sigma f)$ and the total area of the coating (At) was calculated using Equation 1.

$F=\frac{\sum f}{A t}$

Eq. 1

$\mathrm{F}$ is the cracking susceptibility, $\mathrm{mm} / \mathrm{cm}^{2}$;

$\Sigma \mathrm{f}$ is the sum of the cracks' lengths, mm; and

At is the total area of the coating, in $\mathrm{cm}^{2}$.

To determine the restrained volumetric shrinkage, a $30 \times 30 \times 3 \mathrm{~cm}^{3}$ metallic mould was filled with cement-soil mortar in a single layer (Figure 3), consolidated manually with a $10 \mathrm{~mm}$ diameter rod. For each cement-soil mortar dosage, two testplates were moulded and placed on a site with controlled temperature and relative moisture. One of the test-plates was exposed to the airstream, with a velocity controlled by anemometer equipment. With the pachymeter and a fissure ruler, the volume variation of the test-plate was measured at pre-marked points of the mould. These measurements were made every 30 minutes for the first 4 hours and then 24 and 48 hours later. The volumetric shrinkage index was calculated (Equation 2), relating the loss of volume of the test-plate.

$R=\left(1-\frac{V o}{V f}\right) * 1000$

$\mathrm{R}$ is the volumetric shrinkage index;

$\mathrm{V}_{\mathrm{o}}$ is the initial volume of the test-plate, $\mathrm{mm}^{3}$; and

$\mathrm{V}_{\mathrm{f}}$ is the final volume of the test-plate, $\mathrm{mm}^{3}$.

\section{Results and discussion}

The results of the dosage study of cement-soil mortars are shown in Figures 4 and 5, which relate the rich, median and poor dosages with their equivalent values of compressive strength at 28 days and its water retention capacity.

As shown in Figure 4, regardless of the type of soil, both kinds of mortars (made with hydrated lime or admixture) present a significant decrease in the compressive strength values as the proportion of soil increases. It should also be observed that, regardless of the lime or admixture used, the dosages classified as rich, median and poor present a similar mechanical strength.

On the other hand, the lime proportion on the dosages reflect a smaller correlation index $\left(\mathrm{R}^{2}=\right.$ 0.85 ) between the proportion of soil in the dosage and the compression test. Comparing the cementlime-soil mortars with the same soil proportion, the decrease in lime dosage results in higher mechanical strength due to the larger specific surface of the lime, which consumed a higher rate of water to achieve the same consistency (Table 1) and consequently resulted in a greater porosity and lower mechanical strength (SILVA; CAMPITELI, 2006).

Figure 3 - (a) Restrained volumetric shrinkage test; and (b) Test with airstream

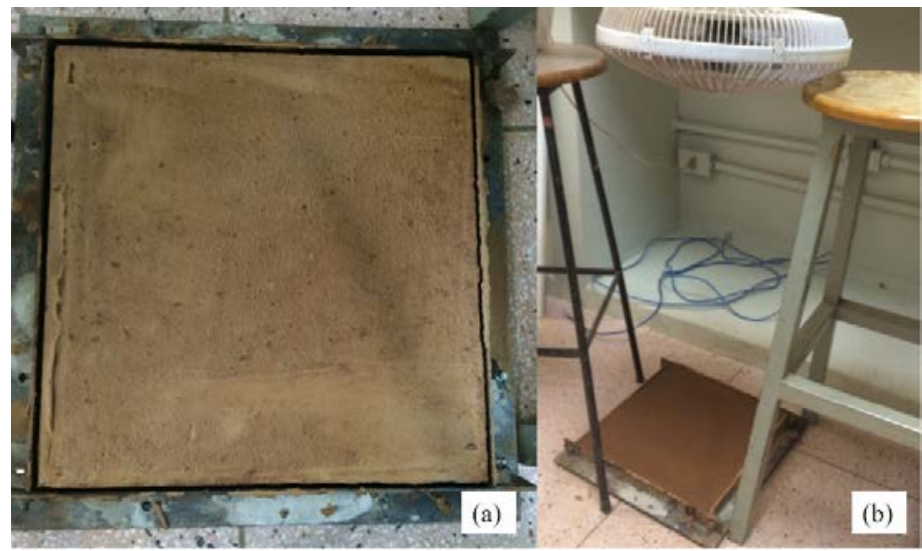

136 Milani, A. P. da S.; Dias, F. G. R. 
Figure 4 - Relation of the soil proportion and compressive strength of the dosage at 28 days

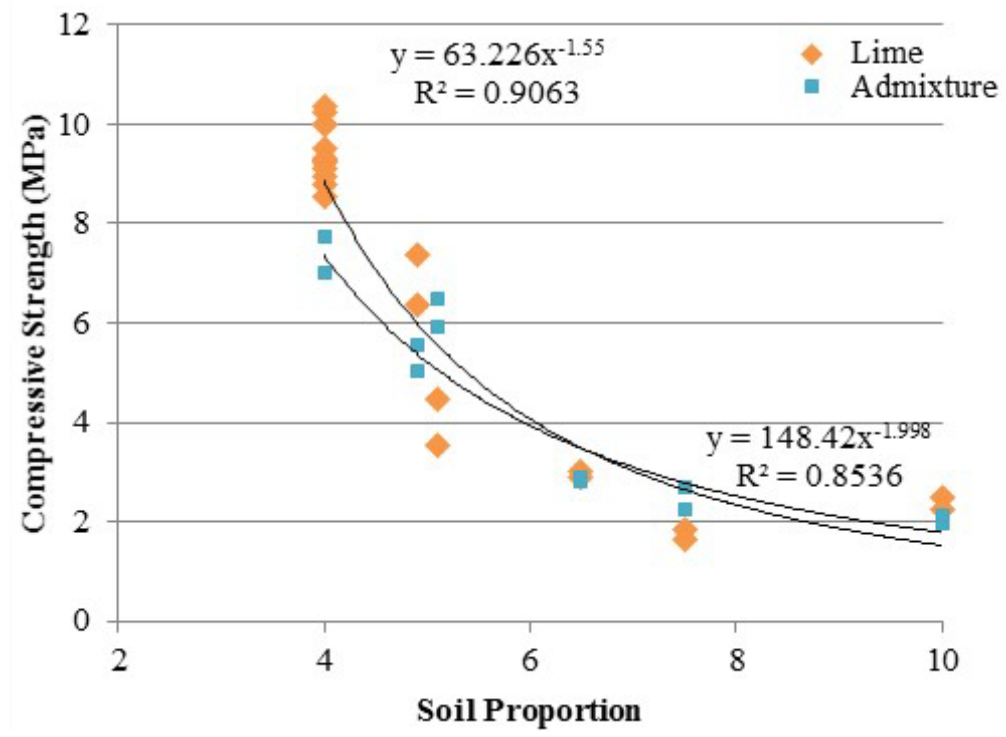

Doubling the proportion of the admixture agent does not significantly decrease the water/cement ratio in the soil-cement mixture. Consequently, it does not interfere in its mechanical strength. The conclusion drawn from this analysis shows that the rate of $0.4 \%$ of admixture is enough to provide workability and mechanical strength for the cement-soil mortars.

Figure 4 also shows that when the soil proportion varies from rich to medium dosages, the mechanical strength is significantly reduced, varying from 10 to $3 \mathrm{MPa}$. The mechanical strength stabilises at the proportion of soil equal to 6.5. Therefore, the poor dosages have an average compressive strength around 3 to $1.5 \mathrm{MPa}$.

Regarding the water retention study (Figure 5), it can be observed that the type and quantity of addition does not show a great influence over the quantity of retained water, which remains around 96.5\% and 99\%. Those values indicate that the cement-soil dosages on fresh state are adequate for wall coatings.

The compressive strength and water retention capacity characteristics of the cement-soil mortars are not significantly influenced by using sand in the dosages. It is worth emphasising that using admixture agent and hydrated lime leads the mortars to the same behaviour when considering mechanical strength and water retention, which confirms the function of keeping the workability on the mortar when submitted to water loss in a fresh state.
After applying the statistic treatment and classification by minimal criteria stated in this study, the dosages used as wall coatings on the masonry blocks are presented in Table 1 .

The cement-soil mortar evaluation shows that, in the fresh state, all dosages are homogenous, with no segregation or exudation, but all of them have worse workability than conventional mortars as cement-soil mortars have a higher density and cohesion between their particles. These two factors make the initial application harder, demanding more time for coating. The cement-soil mortars with the best application were the sandy type, because they have a smaller quantity of clay and silt. An increase in workability in the mortars with an addition of admixture was also observed.

Bonding is a fundamental characteristic to ensure a good performance as a coating mortar, since shear and tensile are common in wall coatings. The standard NBR 13528 (ABNT, 2005b) establishes that $66.67 \%$ of the tensile bond strength test results must be greater than or equal to $0.3 \mathrm{MPa}$ so the mortar is ideal to be used as an external coating mortar, and greater than or equal to $0.2 \mathrm{MPa}$ to be used as an internal mortar. Therefore, mortars with sandy-clay soil added admixture or hydrated lime (maximum ratio of 0.6 by soil weight) are acceptable to be used in earth construction internal coating (Table 1). Although the sandy-clay soil medium mortar with an addition of admixture does not reach the minimum bond strength value, it presents potentiality to use due to its low coefficient of variation. 
Figure 5- Relation between the soil proportion and water retention

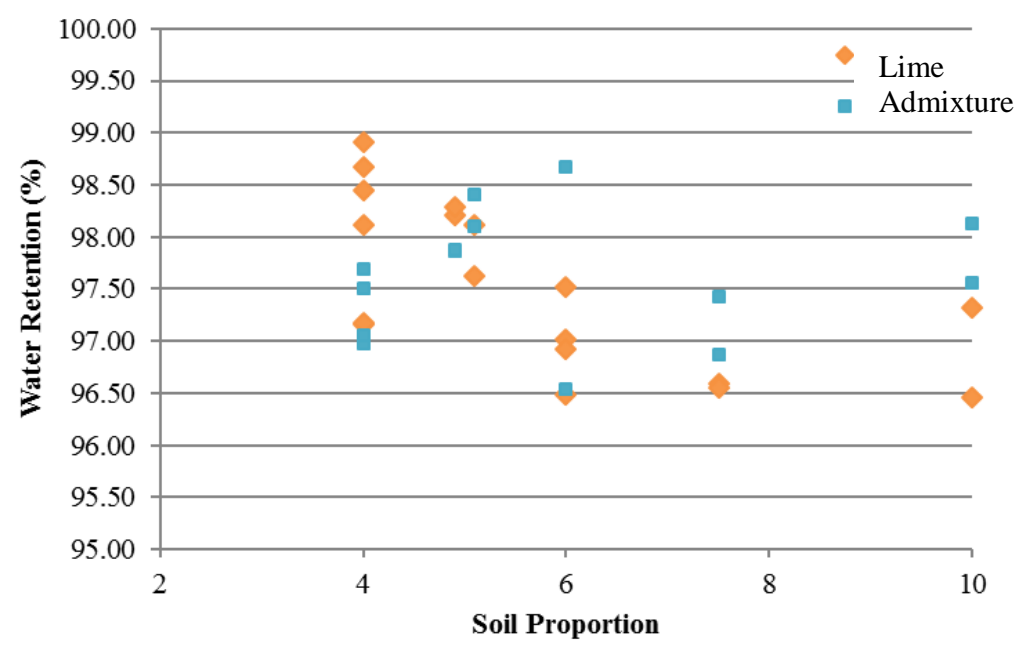

Table 1 - Cement-soil mortar proportion applied as wall coating and its tensile bond strength values

\begin{tabular}{|c|c|c|c|c|c|c|c|c|c|}
\hline $\begin{array}{c}\text { Soil } \\
\text { Type } \\
\text { (by } \\
\text { weight) } \\
\end{array}$ & C & Lime & Soil & Sand & $\begin{array}{l}\text { Admix- } \\
\text { ture (\%) }\end{array}$ & $\begin{array}{c}\text { Ratio } \\
\text { Water/ } \\
\text { Cement }\end{array}$ & $\begin{array}{c}\text { Cement } \\
\text { Consumption } \\
\left(\mathbf{k g} / \mathbf{m}^{3}\right)\end{array}$ & $\begin{array}{l}\text { Batch } \\
\text { Class }\end{array}$ & $\begin{array}{c}\text { Tensile bond } \\
\text { strength } \\
\text { (MPa)* }\end{array}$ \\
\hline Sandy & 1 & 0.6 & 2.66 & 1.24 & - & 1.14 & 290.00 & Rich & $\begin{array}{c}\mathbf{0 . 0 8 ~ d} \\
\pm 0.01(12.50) \\
\end{array}$ \\
\hline Sandy & 1 & 1.2 & 3.55 & 1.50 & - & 1.80 & 205.00 & Medium & $\begin{array}{c}\mathbf{0 . 0 3} \mathbf{e} \\
\pm 0.01(33.30) \\
\end{array}$ \\
\hline Sandy & 1 & - & 3.55 & 1.50 & 0.4 & 1.00 & 260.00 & Medium & $\begin{array}{c}\mathbf{0 . 1 7} \mathbf{~ c} \\
\pm 0.03(17.30)\end{array}$ \\
\hline $\begin{array}{l}\text { Sandy- } \\
\text { Clay }\end{array}$ & 1 & 0.4 & 4 & - & - & 1.10 & 324.53 & Rich & $\begin{array}{c}\mathbf{0 . 2 8} \mathbf{b} \\
\pm 0.02(6.03) \\
\end{array}$ \\
\hline $\begin{array}{l}\text { Sandy- } \\
\text { Clay }\end{array}$ & 1 & 0.4 & 6 & - & - & 1.56 & 233.24 & Medium & $\begin{array}{c}\text { 0.22 c } \\
\pm 0.05(20.69) \\
\end{array}$ \\
\hline $\begin{array}{l}\text { Sandy- } \\
\text { Clay }\end{array}$ & 1 & 0.6 & 4 & - & - & 1.20 & 306.10 & Rich & $\begin{array}{c}\mathbf{0 . 3 5} \mathbf{a} \\
\pm 0,05(15,20)\end{array}$ \\
\hline $\begin{array}{l}\text { Sandy- } \\
\text { Clay }\end{array}$ & 1 & 0.6 & 6 & - & - & 1.56 & 228.68 & Medium & $\begin{array}{c}\mathbf{0 . 2 8} \mathbf{b} \\
\pm 0.02(8.14) \\
\end{array}$ \\
\hline $\begin{array}{l}\text { Sandy- } \\
\text { Clay }\end{array}$ & 1 & 1.2 & 5 & - & - & 1.98 & 217.00 & Medium & $\begin{array}{c}\text { 0.04 e } \\
\pm 0.02(39.80)\end{array}$ \\
\hline $\begin{array}{l}\text { Sandy- } \\
\text { Clay }\end{array}$ & 1 & - & 4 & - & 0.4 & 0.93 & 364.37 & Rich & $\begin{array}{c}\mathbf{0 . 2 8} \mathbf{b} \\
\pm 0.08(29.05)\end{array}$ \\
\hline $\begin{array}{l}\text { Sandy- } \\
\text { Clay }\end{array}$ & 1 & - & 5 & - & 0.4 & 1.05 & 270.30 & Medium & $\begin{array}{c}\mathbf{0 . 2 3} \mathbf{c} \\
\pm 0.02(8.69) \\
\end{array}$ \\
\hline $\begin{array}{l}\text { Sandy- } \\
\text { Clay }\end{array}$ & 1 & - & 6 & - & 0.4 & 1.28 & 260.39 & Medium & $\begin{array}{c}\mathbf{0 . 1 7} \mathbf{c} \\
\pm 0.02(9.58)\end{array}$ \\
\hline
\end{tabular}

Note: *tensile bond strength value \pm standard deviation (coefficient of variation \%); for comparison between different mortars, in each column, averages followed by the same lowercase letter do not differ in the Tukey's test ( $p \varangle 0.05)$.

Most of the ruptures of the mortars that obtained acceptable strength values, according to the standard, were classified as " $\mathrm{B}$ ". This type of rupture is cohesive and occurs inside the mortar. Therefore, there is no significance because it does not have any potential for pathologies.

Mortars with soil, sand, cement and lime have the lowest values of tensile bond strength, followed by the mortars with higher lime proportions (Table 1). According to Azeredo, Morel and Barbosa (2007), the hydrated lime reacts chemically with illite and montmorinolite that exists in clay particles, resulting in the stabilisation of the cement-soillime composite. Adding sand decreases the proportion of clay mineral particles that need to be stabilised, increasing the powdery material created 
by lime, which will increase shrinkage and decrease adherence capacity. This soil comprises mostly quartz and dolomite (MILANI; SILVA, 2016), which indicates a better stabilisation with cement. The lime might cause volumetric instability in the cement-soil composite. Therefore, a limit in the proportion of lime is established to ensure an increase in workability without interfering negatively in its physical-mechanic behaviour.

It can also be observed in Table 1 that the bond strength in the cement and sandy-clay coatings, except for the dosages with higher lime proportions, does not vary with the addition of lime or admixture. However, the class of dosage is important to increase adherence, in other words, the higher the proportion of soil in the mortar dosage, the lower the tensile bond strength of the mortars.

Although the compression test was an initial parameter in the study of the behaviour of cementsoil mortars, the compression test is not a good correlation with the coating's tensile bond strength as the mortars with sandy soil classified as rich or medium obtained high values of compressive strength, but do not have good adherence, showing low values of tensile bond strength. Therefore, the type of soil, the type and ratio of admixture is essential for studying the cement-soil mortar dosage for bonding as soil has a different behaviour to conventional mortars, due to the presence of silt and clay. The soil needs a physicalchemical or mechanical stabilisation to be used as a construction material.

Thus, Ceped (CENTRO..., 1984) created the "box test" to verify the viability of the soil to be used with the compacted soil-cement technique. This test consists of mixing the soil with water until it achieves a plastic consistency and then consolidating it manually in a rectangular mould, dimensions of $60 \times 8.5 \times 3.5 \mathrm{~cm}^{3}$. After seven days in a shaded area, the shrinkage is measured in the length of the box. According to Ceped (CENTRO..., 1984) and NZS 4298 (STANDARD..., 1998), the sum of cracks between the walls of the mould and the test-plate must be less than $20 \mathrm{~mm}$ and the test plate must not have a transversal crack.

After adaptations in the Ceped (CENTRO..., 1984) test, the volumetric shrinkage and cracking test was adopted as criteria to determine the performance of the mortars. The results of these tests were related to the tensile bond and compressive strength as these parameters show a significant influence with the type of soil and cementitious stabiliser rate.

Considering the minimum value of tensile bond strength of $0.2 \mathrm{MPa}$ within their respective standard deviation intervals, the mortars in Table 2 were chosen to receive an addition of polypropylene (PP) microfibres and to be tested in the volumetric shrinkage and cracking test.

The mortars with lime have a high susceptibility to cracking due to drying, while the mortars with admixture are stabilised both in the shrinkage process and in the absence of cracks (Table 2). The admixture agent can reduce the water consumption without reducing its water retention capacity (Table 1). Therefore, there is less free water in the mixture to be evaporated, reducing the volumetric variation of the mortars and consequently leading to lower stresses in the coating.

Table 2 - Relation between tensile bond strength, volumetric shrinkage index and susceptibility to cracking

\begin{tabular}{c|c|c|c|c}
\hline Proportion & Bond Strength & Susceptibility to & \multicolumn{2}{|c}{ Volumetric Shrinkage Index (\%) } \\
\cline { 4 - 5 } cement:lime:type soil & Interval (MPa) & cracking $\left(\mathbf{m m} / \mathbf{c m}^{\mathbf{2}}\right)$ & Control & Airflow \\
\hline 1:0:5 (admixture +sand) & $0.14-0.20$ & 0.00 & 0.000 & 0.703 \\
1:0:4 (admixture) & $0.20-0.36$ & 0.00 & 0.000 & 0.633 \\
1:0:4 (admixture + PP) & $0.17-0.21$ & 0.00 & 0.000 & 0.656 \\
1:0:6 (admixture) & $0.16-0.21$ & 0.00 & 0.000 & 0.622 \\
1:0:6 (admixture + PP) & $0.11-0.13$ & 0.00 & 0.000 & 0.656 \\
1:0.4:4 (lime) & $0.26-0.30$ & 0.697 & 0.211 & 1.667 \\
1:0.4:4 (lime +PP) & $0.09-0.15$ & 0.417 & 0.106 & 0.867 \\
1:0.4:6 (lime) & $0.17-0.27$ & 0.259 & 0.200 & 1.889 \\
1:0.4:6 (lime +PP) & $0.12-0.18$ & 0.182 & 0.256 & 0.833 \\
1:0.6:4 (lime) & $0.30-0.35$ & 0.455 & 0.211 & 1.556 \\
1:0.6:4 (lime + PP) & $0.12-0.16$ & 0.520 & 0.103 & 0.689 \\
1:0.6:6 (lime) & $0.26-0.30$ & 0.820 & 0.244 & 1.667 \\
1:0.6:6 (lime + PP) & $0.08-0.10$ & 0.565 & 0.356 & 0.833 \\
\hline
\end{tabular}


Adding polypropylene (PP) microfibres to the cement-soil-lime mortars decreased the volumetric shrinkage when it was exposed by the airflow. This behaviour is expected because of the mechanical action of the microfibre (ALY; SANJAYAN; COLLINS, 2008). However, the fibres reduced the tensile bond strength of all the cement-soil mortar tested. This can be explained by the increase of the specific area by the presence of fibres and consequent decrease in the soil stabilisation process, thus reflecting in the lower adherence of the cement-soil mortar in the earth substrate.

The determination of volumetric shrinkage through a box under controlled environmental conditions can be a preliminary test applicable in the choice of the soil type and the type and content of additions to obtain a good physical performance of cement-soil mortars against cracking susceptibility. The results in Table 2 corroborate the behaviour found in the literature for earth construction, where observing the physical performance of the stabilised earth through cracking and shrinkage tests will indicate its potential to be used as a matrix of the building material (MANIATIDIS; WALKER, 2003).

In contrast to the conclusions found with the behaviour on the tensile bond strength and compressive strength test (Figure 4 and Table 1), the type of addition (admixture or hydrated lime) is a relevant factor for achieving a better physical behaviour of cement-soil mortars against shrinkage and cracking (Table 2). Similar values of volumetric shrinkage index were found for cement-soil-lime mortars with tensile bond strength between 0.17 and $0.35 \mathrm{MPa}$, as well as null values of shrinkage and cracking for the cement-soil-addition mortars.

There is no direct correlation between the physical-mechanical parameters of cement-soil mortars, i.e., it did not follow the relation of the greater the bonding and compression strength, the better the performance of the cracking and shrinkage (Figure 4 and Table 2). However, there is a dependence between these parameters, because there is an ideal range of cement and addition ratio to be incorporated into the soil mortar while achieving suitable properties in the fresh and hardened state compatible for use and durability of the coating.

The cement-soil mortars that are not susceptible to cracking showed a minimum compressive strength of $4 \mathrm{MPa}$ and water retention greater than $96 \%$ (Figures 4 and 5 and Tables 1 and 2). However, it should be noted that the tensile bond strength is another important factor to be evaluated in the performance of coating mortar, because it indicates the behaviour considering strain and tensile, and the potential for the occurrence of pathological manifestations. Therefore, the cement-soil mortar must have minimum cracking susceptibility and adequate strength for use in earth-wall coating, and the minimum requirements for volumetric shrinkage (control), bonding and compression strength must be met simultaneously, considering the following criteria: minimum compressive strength of $4 \mathrm{MPa}$; zero volumetric shrinkage index and minimum tensile bond strength of 0.20 $\mathrm{MPa}$.

\section{Conclusions}

Cement-soil mortar is a suitable alternative for earth wall coating to achieve durability and conservation of earth buildings, as there is mechanical compatibility between the components of the system. It is recommended to use a proportion of sandy soil type less than or equal to 1:6 (cement:soil), as it achieves satisfactory results to be used as earth wall coating. In order to improve the workability in the fresh state of the cement-soil mortars, the chemical admixture and hydrated lime can be used at an adequate proportion to avoid stress in the coating during drying. The use of hydrated lime at a maximum ratio of 1:0.6:X in the cement:lime:soil mortar (by weight) results in minimum bonding and compression strengths suitable to be used as earth wall coatings, but entails high susceptibility to cracking due to drying. The addition of admixture at the optimum content $0.4 \%$ (by weight of cement) results in more stable cement-soil mortars under the aspects of good mechanical performance and greater control in the cracking and shrinkage process.

The proposed volumetric shrinkage test method was suitable for measuring the drying shrinkage of cement-soil mortars due to its simplicity, convenience and reproducibility. Moreover, it is an important parameter of physical performance, because even when presenting high values of mechanical strength the coatings can present high susceptibility to cracking due to drying. Therefore, to verify the potentiality of cement-soil mortars for the coating of earth buildings, volumetric shrinkage parameters, compressive strength and bond strength are recommended. To qualify the cement-soil mortars for earth building coating, the minimum requirements for volumetric shrinkage, tensile bond strength and compressive strength must be met simultaneously, and the following physical-mechanical performance criteria are recommended: minimum compressive strength of 
$4 \mathrm{MPa}$; zero volumetric shrinkage index and minimum tensile bond strength of $0.20 \mathrm{MPa}$.

\section{References}

ALY, T.; SANJAYAN, J. G.; COLLINS, F. Effect of Polypropylene Fibers on Shrinkage and Cracking of Concretes. Materials and Structures, v. 41, p. 1741-1753, 2008.

AMERICAN SOCIETY FOR TESTING AND MATERIALS. ASTM C-1579: standard test method for evaluating plastic shrinkage cracking of restrained fiber reinforced concrete (using a steel form insert). Philadelphia, 2006.

AMERICAN SOCIETY FOR TESTING AND MATERIALS. ASTM C-780: standard test method for preconstruction and construction evaluation of mortars for plain and reinforced unit masonry. Philadelphia, 2009.

ARIZZI, A.; CULTRONE, G. The influence of Aggregate Texture, Morphology and Grading on the Carbonation of Non-Hydraulic (Aerial) LimeBased Mortars. Quarterly Journal of Engineering Geology and Hydrogeology, v. 46, p. 507-520, 2013.

\section{ASSOCIAÇÃO BRASILEIRA DE NORMAS} TÉCNICAS. NBR 13281: argamassa para assentamento e revestimento de paredes e tetos: requisitos. Rio de Janeiro, 2005a.

ASSOCIAÇÃO BRASILEIRA DE NORMAS TÉCNICAS. NBR 13528: revestimento de paredes e tetos de argamassas inorgânicas: determinação da resistência de aderência à tração. Rio de Janeiro, 2005b.

\section{ASSOCIAÇÃO BRASILEIRA DE NORMAS}

TÉCNICAS. NBR 13749: revestimento de paredes e tetos de argamassas inorgânicas: especificação. Rio de Janeiro, 1996.

AZEREDO, G. A.; MOREL, J. C.; BARBOSA, N. P. Compressive Strength Testing Of Earth Mortars. Journal of Urban and Environmental Engineering, v. 1, n. 1, p. 26-35, 2007.

BURROUGHS, S. Soil Property Criteria for Rammed Earth Stabilization. Journal of Materials in Civil Engineering, v. 20, n. 3, p. 264-73, 2008.

CARASEK, H. et al. Bond Between 19th Century Lime Mortars and Glazed Ceramic Tiles.

Construction and Building Materials, v. 59, p. 85-98, 2014.

CENTRO DE PESQUISAS E DESENVOLVIMENTO. Manual de Construção Com Solo-Cimento. 3. ed. São Paulo: Ceped, 1984.
CENTRE SCIENTIFIQUE ET TECHNIQUE DU

BÂTIMENT. Note D'information Sur les

Caractéristiques et le Comportement des Enduits Extérieurs D'imperméabilisation de Murs à Base de Liants Hidraulyques. Paris: Livraison, 1982.

CORREIA, M. et al. Arquitectura de Tierra en América Latina. Lisboa: Argumentum, 2016.

FERREIRA, G. C. S.; MORENO JÚNIOR, A. L. Cola à Base de PVA e Argamassa de SoloCimento Como Alternativas Para o Assentamento de Alvenaria de Tijolos Maciços de Solo-Cimento. Revista Engenharia Agrícola, v. 31, n. 2, p. 237 248, 2011.

GATTESCO, N.; BOEM, I.; A. DUDINE, A. Diagonal Compression Tests on Masonry Walls Strengthened With a GFRP Mesh Reinforced Mortar Coating. Bulletin Earthquake Engineering, v. 13, p. 1703-1726, 2015.

KANAN, M. I. Manual de Conservação e Intervenção em Argamassas e Revestimentos à Base de Cal. Brasília: Iphan, 2008.

KARIYAWASAM, K. K. G. K. D.; JAYASINGHE, C. Cement Stabilized Rammed Earth as a Sustainable Construction Material. Construction \& Building Materials, v. 105, p. 519-527, 2016.

MA, Y. et al. Effect of Type Polypropylene Fiber on Plastic Shrinkage Cracking of Cement Mortar. Materials and Structures, v. 37, n. 2, p. 92-95, 2004.

MANIATIDIS, V.; WALKER, P. A Review of Rammed Earth Construction for DTi Partners in Innovation Project 'Developing Rammed Earth for UK Housing'. University of Bath, 2003.

MATEUS, L. P.; VEIGA, M. R.; de BRITO J. Caracterização de Argamassas de Proteção Exterior de Suportes em Terra Compactada. In: CONGRESSO LATINO-AMERICANO DE PATOLOGIA DA CONSTRUÇÃO, 13., Lisboa, 2015. Proceedings... Lsiboa: ALCONPAT, 2015.

MAUROUX, T. et al. Study of Cracking Due to Drying in Coating Mortars by Digital Image Correlation. Cement and Concrete Research, v. 42, n. 7, p. 1014-1023, 2012.

MILANI, A. P.S.; SILVA, C. I. Study of Physical and Chemical Interactions of Soil-Cement Mixtures and Additive Superplasticizer. In: AMAZON \& PACIFIC GREEN MATERIALS CONGRESS; SUSTAINABLE CONSTRUCTION MATERIALS LAT-RILEM CONFERENCE, 6., Colombia, 2016. Proceedings... Colombia, 2016. 
OLIVEIRA, T. et al. The Effect of the Substitution of Hydrated Lime With Phyllite on Mortar Quality. Applied Clay Science, v. 105/106, p. 113-117, 2015.

REDDY, B. V. V.; GUPTA, A. Characteristics of Cement-Soil Mortars. Materials and Structures, v. 38, n. 6, p. $639-650,2005$.

REDDY, B. V. V.; GUPTA, A. Influence of Sand Grading on the Characteristics of Mortars and Soil-Cement Block Masonry. Construction and Building Materials, v. 22, n. 8, p. 1614-1623, 2008.

REDDY, B. V. V.; GUPTA, A. Tensile Bond Strength of Soil-Cement Block Masonry Couplets Using Cement-Soil Mortars. Journal of Materials in Civil Engineering, v. 18, n. 1, p. 36-45, 2006.

REDDY, B. V.; KUMAR, P. P. Cement Stabilised Rammed Earth: part B: compressive strength and stress-strain characteristics. Materials and Structures, v. 44, p. 695-707, 2011.

ROMERA, J. I. et al. Assessment of the physicomechanical behaviour of gypsum-lime repair mortars as a function of curing time.

Environmental Earth Sciences, v. 70, n. 4, p. 1605-1618, 2013.
SILVA, N. G.; CAMPITELI, V. C. Influência dos Finos e da Cal nas Propriedades das Argamassas. In: ENCONTRO NACIONAL DE TECNOLOGIA DO AMBIENTE CONSTRUÍDO. 11., Florianópolis, 2006. Anais... Florianópolis: ENTAC, 2006.

STANDARD NEW ZEALAND. NZS 4298: materials and workmanship for earth buildings. Wellington, 1998.

SYRMAKEZIS, K. et al. Finite Element Analysis and Fragility Curves for the Evaluation of Restoration Mortars Behavior Regarding the Earthquake Protection of Historic Structures. Soil Dynamics and Earthquake Engineering, v. 54, p. 61-65, 2013.

TOLEDO FILHO, R. D. et al. Free, Restrained and Drying Shrinkage of Cement Mortar Composites Reinforced With Vegetable Fibres. Cement and Concrete Composites, v. 27, n. 5, p. 537-546, 2005.

VERALDO, A. C.; YUBA, A. N.; MILANI, A. P. S. Procedimentos Expeditos Para Medição in loco de Patologias de Paredes de Taipa. In:

LATIN-AMERICAN AND EUROPEAN CONFERENCE ON SUSTAINABLE BUILDINGS AND COMMUNITIES, 1., Lisboa, 2015. Proceedings... Lisboa, 2015.

\section{Ana Paula da Silva Milani}

Faculdade de Engenharias, Arquitetura e Urbanismo e Geografia | Universidade Federal de Mato Grosso do Sul | Av. Costa e Silva, s/n, Bairro Universitário | Campo Grande - MS - Brasil | CEP 79070-900 | Tel.: (67) 3345-7478 | E-mail: ana.milani@ufms.br

Flávia Gaspar Rangel Dias

Faculdade de Engenharias, Arquitetura e Urbanismo e Geografia | Universidade Federal de Mato Grosso do Sul | Tel.: (67) 3345-7476 | E-mail: flaviagrdias@gmail.com

Revista Ambiente Construído

Associação Nacional de Tecnologia do Ambiente Construído

Av. Osvaldo Aranha, 99 - 3o andar, Centro

Porto Alegre - RS - Brasil

CEP $90035-190$

Telefone: +55 (51) 3308-4084

Fax: +55 (51) 3308-4054

www. seer. ufrgs. br/ ambienteconstruido

E-mail: ambienteconstruido@ufrgs.br 